\title{
Irrigation and organic fertilization on the production of essential oil and flavonoid in chamomile
}

\author{
Catariny C. Aleman ${ }^{1} \&$ Patricia A. A. Marques ${ }^{2}$ \\ ${ }^{1}$ Universidade Federal de Viçosa/Departamento de Engenharia Agricola. Viçosa, MG. E-mail: catariny@ufv.br (Corresponding author) \\ ${ }^{2}$ Universidade de São Paulo/Escola Superior de Agricultura "Luiz de Queiroz"/Departamento de Engenharia de Biossistemas. Piracicaba, SP. E-mail: \\ paamarques@usp.br
}

\section{Key words:}

Chamomilla recutita (L.) Rauschert medicinal plants

water stress

irrigation management

organic production

\begin{abstract}
A B S T R A C T
The therapeutic efficacy of herbal medicines and pesticides has increased the need to define cultivation parameters for medicinal plants. The objective of this study was to evaluate the production of essential oil and flavonoids of chamomile under irrigation levels and organic fertilizer doses. The experiment was conducted in the experimental area of the Campus II of the University of Western São Paulo, in the city of Presidente Prudente, SP, Brazil. The experimental design was a randomized block in triple factorial $(6 \times 2 \times 3)$, corresponding to irrigation depths $(150,100,75,50,25$ and $0 \%$ of the reference evapotranspiration (ETo)), organic fertilizers (poultry manure and cattle manure) and the fertilizer doses (0, 3 and $5 \mathrm{~kg} \mathrm{~m}^{-2}$ ), with four replicates. The following variables were evaluated: capitulum dry matter, and content and yield of essential oil and flavonoids. For the tested conditions, it is recommended to use $5 \mathrm{~kg} \mathrm{~m}^{-2}$ poultry manure and water depth equivalent to $150 \%$ ETo for the production of essential oil and flavonoid.
\end{abstract}

\section{Palavras-chave:}

Chamomilla recutita (L.) Rauschert

planta medicinal

estresse hídrico

manejo de irrigação

produção orgânica

\section{Irrigação e adubação orgânica na produção de óleo essencial e flavonoides em camomila}

\begin{abstract}
R E S U M O
A eficácia terapêutica de fitoterápicos e fitofármacos tem aumentado a necessidade de definir parâmetros de cultivo para plantas medicinais. O objetivo do presente trabalho foi avaliar a produção de óleo essencial e flavonoides da camomila quanto a lâminas de irrigação e doses de adubo orgânico. O experimento foi conduzido em área experimental do Campus II, da Universidade do Oeste Paulista, na cidade de Presidente Prudente, SP, Brasil. O delineamento experimental foi em blocos ao acaso em esquema fatorial triplo ( 6 × 2 x 3), sendo a lâmina de irrigação $(150,100,75,50,25$ e $0 \%$ da evapotranspiração de referência (ETo)), o adubo orgânico (esterco de aves e esterco bovino curtido) e a dose do adubo (0, 3 e $\left.5 \mathrm{~kg} \mathrm{~m}^{-2}\right)$ e quatro repetições. Foram avaliados a massa seca de capítulos florais, o teor e o rendimento de óleo essencial e o flavonoide; para as condições testadas recomenda-se utilizar $5 \mathrm{~kg} \mathrm{~m}^{-2}$ de esterco de ave e lâmina de irrigação equivalente a 150\% ETo para a produção de óleo essencial e flavonoide.
\end{abstract}




\section{INTRODUCTION}

Chamomile is a medicinal and aromatic plant of great importance for the cosmetic and phytotherapeutic industry. It is the medicinal plant of greatest economic expression in the South region with cultivated area of 2,000 thousand ha in Paraná (Corrêa Júnior \& Scheffer, 2014).

Irrigation management consists in the rational use of water in order to meet the requirements of the plants, increasing production and water use efficiency (Shock \& Wang, 2011; Pinto et al., 2014; Afshar et al., 2014). The water balance is one way of managing irrigation, considering the processes of absorption, conduction and loss of water. The difference between the water absorbed and lost by the plant is a relevant factor for the metabolic processes of adjustment of the plant (Bilibio et al., 2010).

In situations of water deficit, medicinal plants can activate the secondary metabolism and the osmotic adjustment. The synthesis of secondary metabolites represents the chemical interface between plants and the environment (Gobbo Neto \& Lopes, 2007; Kerbauy, 2008; Tavano et al., 2009). In the osmotic adjustment, the plant tolerates the situation of lower water availability through the accumulation of amino acids that provide the plant with the capacity to maintain its cell expansion, performing stomatal and photosynthetic adjustments, favoring its growth (Taiz \& Zeiger, 2013).

Organic fertilization has a soil-conditioning effect, increasing the cation exchange capacity, contributing to soil aggregation and causing increase in plasticity and cohesion, besides greater water retention and temperature stability. According to Côrrea et al. (2010), the increment of fertilization using bovine manure at the doses of $3,6,9$ and $12 \mathrm{~kg} \mathrm{~m}^{-2}$ significantly contributes to growth and essential oil yield in oregano.

Considering the need to define the adequate levels of irrigation and organic fertilization for the cultivation of medicinal plants, this study aimed to evaluate the influence of irrigation and organic fertilization on the production of flavonoids and essential oil in chamomile.

\section{Material AND Methods}

The experiment was conducted from April to August 2011, in an experimental area of the Campus II of the University of Western São Paulo, in the municipality of Presidente PrudenteSP, Brazil. The experimental design was randomized blocks, in a triple factorial scheme with six irrigation depths associated with two types of organic fertilizer, three doses each, with four replicates, totaling 144 experimental plots. The seedlings were prepared on expanded polypropylene trays with 200 cells, using commercial seeds of chamomile (ISLA ${ }^{*}$ ), which were transplanted to the field 40 days after sowing (DAS). The experimental plots had dimensions of $3 \mathrm{~m} \mathrm{x} 1 \mathrm{~m}$. Fifteen plants were transplanted to each plot at spacing of $0.30 \times 0.40$ $\mathrm{m}$. Irrigation depths equivalent to $100 \%$ of replacement of the reference evapotranspiration (ETo) were applied during the first seven days after transplanting. After this period, the treatments with irrigation depths were established.
The treatments with irrigation depths were $0,25,50,75$, 100 and $150 \%$ ETo, daily applied and based on the PenmanMonteith method (Eq. 1 to 5) recommended by the Food and Agriculture Organization (FAO) as standard (Allen et al., 1998). The meteorological data were obtained from an automatic weather station (Campbell Scientific) installed in the Agrometeorological Station of the UNOESTE, $20 \mathrm{~m}$ away from the experimental area.

$$
\begin{gathered}
\mathrm{ETo}=\frac{0.408 \mathrm{~s}(\mathrm{Rn}-\mathrm{G})+\gamma 900 \mathrm{U}_{2}\left(\frac{\mathrm{es}-\mathrm{ea}}{\mathrm{Td}+273}\right)}{\mathrm{s}+\gamma\left(1+0.34 \mathrm{U}_{2}\right)} \\
\mathrm{G}=0.38\left(\mathrm{~T}_{\mathrm{d}}-\mathrm{T}_{3 \mathrm{~d}}\right) \\
\mathrm{es}=\left\{\frac{0.6108 \mathrm{e}^{\left[\left(17.27 \cdot \mathrm{T}_{\max }\right) /\left(237.7+\mathrm{T}_{\max }\right)\right]}+0.6108 \mathrm{e}^{\left[\left(\left(17.27 \cdot \mathrm{T}_{\min }\right) /\left(237.7+\mathrm{T}_{\min }\right)\right)\right]}}{2}\right\} \\
\mathrm{ea}=\frac{\mathrm{RHes}}{100} \\
\frac{4098 \mathrm{es}}{(\mathrm{T}+237.2)^{2}}
\end{gathered}
$$

where:

ETo - reference evapotranspiration, $\mathrm{mm} \mathrm{d}^{-1}$;

$\mathrm{Rn} \quad$ - daily total net radiation, $\mathrm{MJ} \mathrm{m}^{-2} \mathrm{~d}^{-1}$;

$\mathrm{G} \quad$ - daily total heat flow in the soil, $\mathrm{MJ} \mathrm{m}^{-2} \mathrm{~d}^{-1}$;

$\gamma \quad$ - psychrometric constant, $0.063 \mathrm{kPa}^{\circ} \mathrm{C}^{-1}$;

$\mathrm{U}_{2} \quad$ - wind speed, $\mathrm{m} \mathrm{s}^{-1}$;

es - saturation vapor pressure, $\mathrm{kPa}$;

ea - partial vapor pressure, $\mathrm{kPa}$;

$\mathrm{T}_{\mathrm{d}} \quad$ - mean daily temperature, ${ }^{\circ} \mathrm{C}$;

$\mathrm{T}_{3 \mathrm{~d}} \quad$ - mean daily temperature of 3 days, ${ }^{\circ} \mathrm{C}$;

$\mathrm{T}_{\max } \quad$ - maximum temperature, ${ }^{\circ} \mathrm{C}$;

$\mathrm{T}_{\text {min }} \quad$ - minimum temperature, ${ }^{\circ} \mathrm{C}$;

ea - actual vapor pressure, $\mathrm{kPa}$;

RH - relative air humidity, \%; and,

$\mathrm{T} \quad$ - mean temperature, ${ }^{\circ} \mathrm{C}$.

Doses of organic fertilization were tested in association with the irrigation depths. The fertilization was applied on the same day the seedlings were transplanted to the experimental plots. The fertilizers were aged bovine manure and aged poultry manure, both at the doses of 0,3 and $5 \mathrm{~kg} \mathrm{~m}^{-2}$. The chemical analysis of the fertilizers was performed at the Laboratory of Soils and Plant Nutrition of the UNOESTE. The results for the bovine manure were: total $\mathrm{N}=38.2 \mathrm{~g} \mathrm{~kg}^{-1} ; \mathrm{P}=9.9 \mathrm{~g} \mathrm{~kg}^{-1}$; $\mathrm{K}=24.4 \mathrm{~g} \mathrm{~kg}^{-1} ; \mathrm{Ca}=33.7 \mathrm{~g} \mathrm{~kg}^{-1} ; \mathrm{Mg}=14.2 \mathrm{~g} \mathrm{~kg}^{-1} ; \mathrm{S}=0.7 \mathrm{~g}$ $\mathrm{kg}^{-1} ; \mathrm{B}=35.8 \mathrm{mg} \mathrm{kg}^{-1} ; \mathrm{Cu}=5.04 \mathrm{mg} \mathrm{kg}^{-1} ; \mathrm{Fe}=49.71 \mathrm{mg} \mathrm{kg}^{-1}$; $\mathrm{Mn}=414 \mathrm{mg} \mathrm{kg}^{-1}$ and $\mathrm{Zn}=135 \mathrm{mg} \mathrm{kg}^{-1}$ and, for the poultry manure: total $\mathrm{N}=20.6 \mathrm{~g} \mathrm{~kg}^{-1} ; \mathrm{P}=12.8 \mathrm{~g} \mathrm{~kg}^{-1} ; \mathrm{K}=64.5 \mathrm{~g} \mathrm{~kg}^{-1}$; $\mathrm{Ca}=173 \mathrm{~g} \mathrm{~kg}^{-1} ; \mathrm{Mg}=12 \mathrm{~g} \mathrm{~kg}^{-1} ; \mathrm{S}=7.9 \mathrm{~g} \mathrm{~kg}^{-1} ; \mathrm{B}=40 \mathrm{mg} \mathrm{kg}^{-1}$; $\mathrm{Cu}=183 \mathrm{mg} \mathrm{kg}^{-1} ; \mathrm{Fe}=13.62 \mathrm{mg} \mathrm{kg}^{-1} ; \mathrm{Mn}=339 \mathrm{mg} \mathrm{kg}^{-1}$ and $\mathrm{Zn}=489 \mathrm{mg} \mathrm{kg}^{-1}$. 
The soil of the region is classified as eutrophic Red Yellow Argisol (EMBRAPA, 2013). The physico-chemical analysis of the soil in the experimental area showed the following characteristics: $\mathrm{pH}$ in $\mathrm{CaCl}_{2}=6.2 ; \mathrm{pH}$ in $\mathrm{SMP}=6.9 ; \mathrm{OM}=13$ $\mathrm{g} \mathrm{dm}^{-3} ; \mathrm{H}+\mathrm{AL}=18 \mathrm{mmol}_{\mathrm{c}} \mathrm{dm}^{-3} ; \mathrm{Ca}^{+2}=41 \mathrm{mmol}_{\mathrm{c}} \mathrm{dm}^{-3} ; \mathrm{Mg}^{+2}=$ $21 \mathrm{mmol}_{\mathrm{c}} \mathrm{dm}^{-3} ; \mathrm{K}^{+}=2.6 \mathrm{mmol}_{\mathrm{c}} \mathrm{dm}^{-3} ; \mathrm{P}=69 \mathrm{mg} \mathrm{dm}^{-3} ; \mathrm{SB}=64.6$ $\mathrm{mmol}_{\mathrm{c}} \mathrm{dm}^{-3} ; \mathrm{CEC}=57 \mathrm{mmol}_{\mathrm{c}} \mathrm{dm}^{-3} ; \mathrm{V} \%=58$ and granulometry of $79.5 \%$ of sand, $14 \%$ of clay and $6.5 \%$ of silt, characterizing a sandy textural class. Soil correction was performed 30 days before transplanting using dolomitic limestone with $90 \%$ RNV to increase base saturation to $70 \%$, according to the recommendation of Raij et al. (1997) for chamomile.

The total chamomile cultivation cycle was 128 days after transplanting. The harvest of the central row started 100 days after transplanting with the emergence of the first flowers and was performed daily until the senescence of the plants (duration of 28 days). After harvest, the capitula were dried at temperature of $60^{\circ} \mathrm{C}$ in an oven for 3 days. Then, the flavonoids were extracted from $2 \mathrm{~g}$ of capitula according to the method recommended by Verlag (1978). The essential oil was extracted through the process of hydrodistillation in a Clevenger apparatus using four replicates of $10 \mathrm{~g}$ of capitula in a 3 - $\mathrm{L}$ volumetric flask with $1.5 \mathrm{~L}$ of distilled water, recording the volume of essential oil collected every hour (Wagner \& Bladt, 1995).

The analyzed variables were: total dry matter of the capitula, and content (\% of flavonoid in $100 \mathrm{~g}$ of capitula) and yield ( $\mathrm{g}$ plant $^{-1}$ ) of flavonoids and essential oil. The obtained data were subjected to $\mathrm{F}$ test and regression analysis.

\section{Results AND Discussion}

During the experimental period, there was water deficit with total use of the tested irrigation depths (Figure 1). According to Meira et al. (2013), water deficit has direct effects on vegetative growth, biomass production and contents of secondary metabolites. The water deficit favored the effect of the irrigation depths on chamomile development (Figures 2, 3 and 4), directly interfering with the content of flavonoid and essential oil.
There was no production of capitula in the plots where the organic fertilizer was not applied (Figure 2). According to Amer et al. (2009), organic fertilization favors the improvement of texture and the contents of organic matter and nutrients, contributing to the increase in soil water retention and, consequently, meeting the water requirements of the plant.

For capitulum dry matter (Figure 2), there was a polynomial fit in the interaction between fertilizer doses and irrigation depths, with the highest results of capitulum dry matter at the poultry manure dose of $5 \mathrm{~kg} \mathrm{~m}^{-2}$ associated with the increment in irrigation depth. According to Souza et al. (2012), the fertilization with manures acted on the physical, biological and chemical mechanisms, promoting improvements on the water retention capacity. The improvement on soil structure favors the progressive increments in irrigation depths without causing damages to the plant under water stress condition.

For the content and yield of total flavonoids (Figure 3), there was interaction between irrigation depths and organic fertilization. The quadratic fit demonstrates the progressive

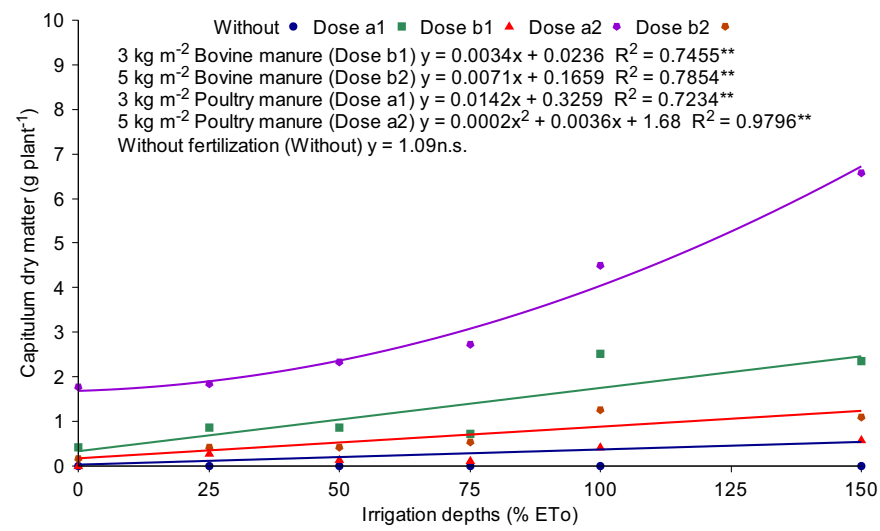

** significant at 0.01 probability level

Figure 2. Capitulum dry matter of chamomile subjected to different irrigation depths (150, 100, 75, 50, 25 and $0 \%$ ETo) and organic fertilization using bovine manure (A) and poultry manure (B), both at the doses of $3 \mathrm{~kg} \mathrm{~m}^{-2}$ (b1 and a1) and $5 \mathrm{~kg} \mathrm{~m}^{-2}$ (b2 and a2), respectively

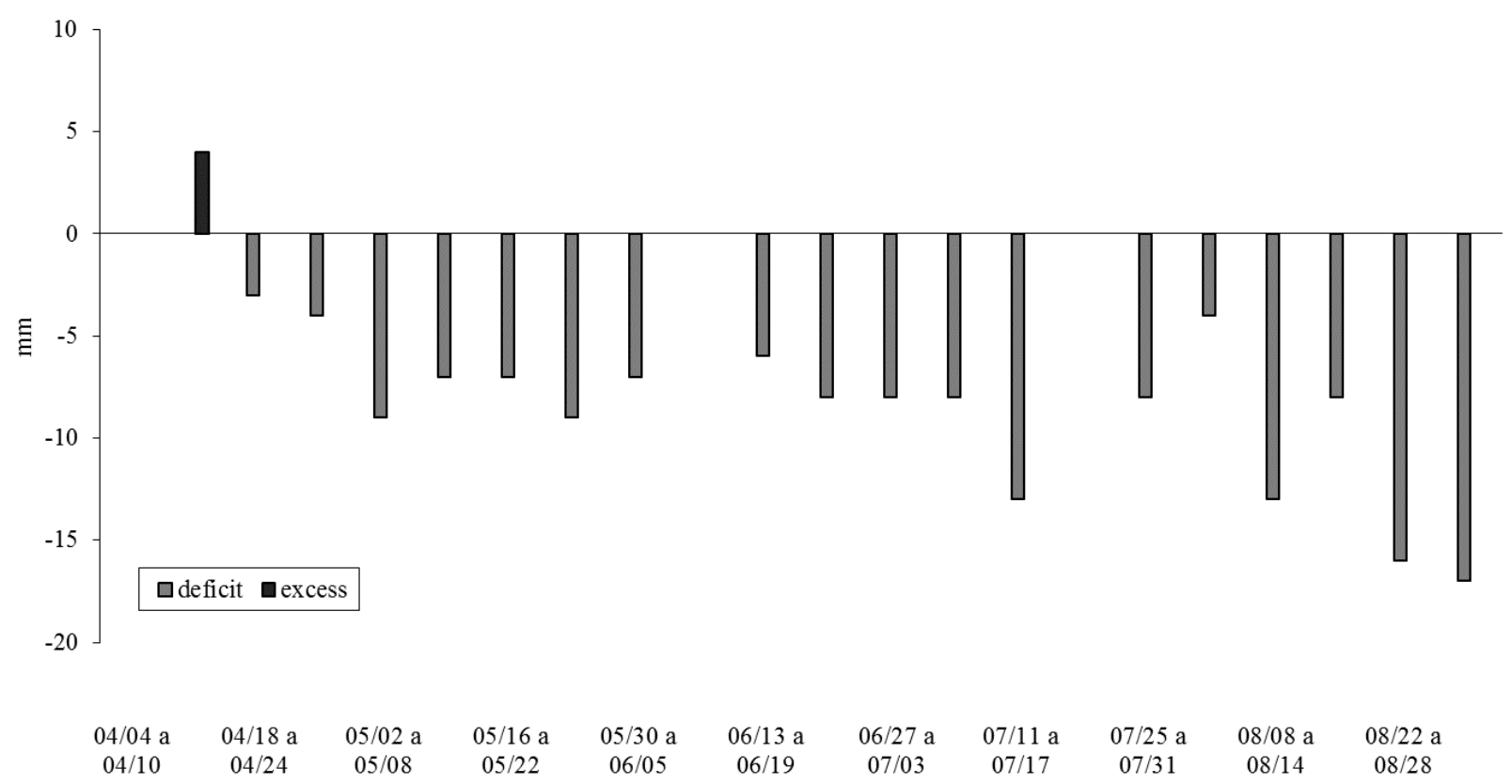

Figure 1. Climatic water balance along the experiment for the water depth of $100 \%$ ETo 


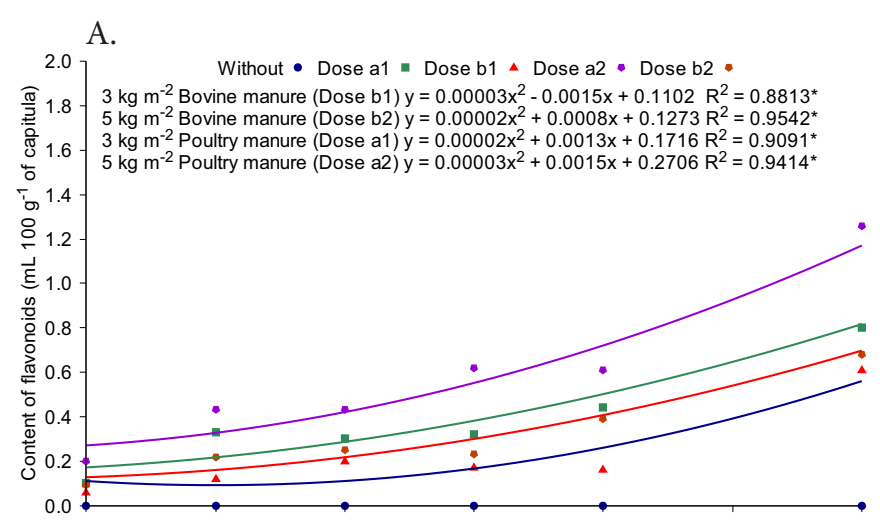

B.

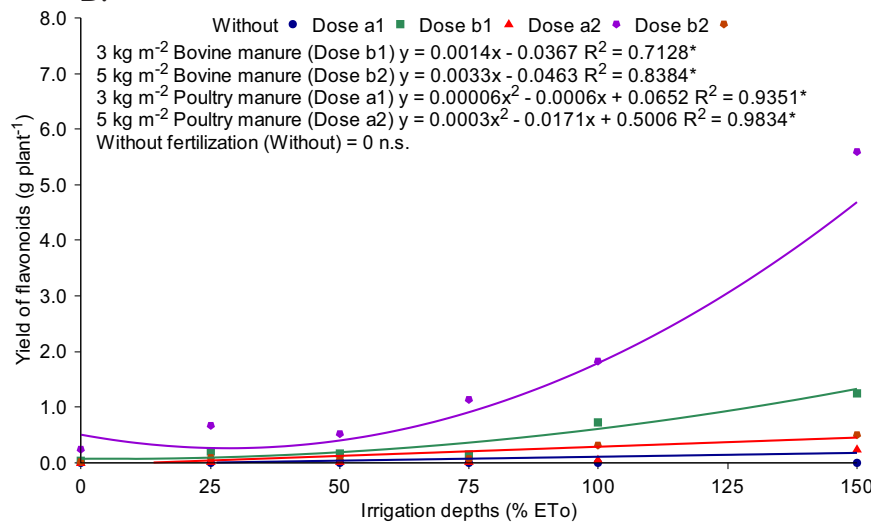

Figure 3. Content (A) and yield (B) of flavonoids in chamomile subjected to different irrigation depths (150, 100, 75, 50, 25 and 0\% ETo) and organic fertilization with bovine manure (b) and poultry manure (a), both at the doses of $3 \mathrm{~kg} \mathrm{~m}^{-2}$ (b1 and a1) and $5 \mathrm{~kg} \mathrm{~m}^{-2}$ (b2 and a2), respectively

increment of the accumulation of flavonoids as the applied irrigation depth increased. The irrigation depth of $150 \%$ ETo associated with the organic fertilization using poultry manure at the dose of $5 \mathrm{~kg} \mathrm{~m}^{-2}$ (dose a2) led to the highest content of total flavonoids and yield of total flavonoids per plant. The results of content of total flavonoids were different from those obtained by Bortolo et al. (2009) and Pacheco et al. (2011); according to these studies, the variation of water availability did not interfere with the concentration of this phenolic compound for the calendula crop. Mitchell et al. (2007) found that the levels of flavonoids in tomato plants increase in the presence of organic fertilization. Borella et al. (2011) observed that the content of total flavonoids did not show significant differences for the treatments using chemical fertilization and organic fertilization in calendula.

In response to the water stress, the plants tend to produce phenolic compounds and other substances for their maintenance under unfavorable conditions. There was a decrease of $25 \%$ in the content of flavonoids between the irrigation depths of $150 \%$ ETo and $0 \%$ ETo for the organic fertilization with poultry manure at the dose of $5 \mathrm{~kg} \mathrm{~m}^{-2}$ (Figure 4A). Alvarenga et al. (2011) concluded that the water deficit caused reduction of $60 \%$ in the content of flavonoids in rosemary pepper (Lippia sidoides).

The irrigation depth of $150 \%$ ETo (Figure $4 \mathrm{~A}$ ), associated with the poultry manure dose of $5 \mathrm{~kg} \mathrm{~m}^{-2}$ resulted in the highest

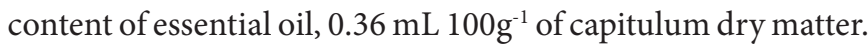
The obtained content was below the minimum required by the Brazilian Pharmacopeia (ANVISA, 2010) (0.4 mL 100 $\left.\mathrm{g}^{-1}\right)$ for commercialization. According to Khan et al. (2012), the highest irrigation depths favored the solubilization of the nutrients and maintenance of transpiration and equilibrium of the photosynthesis, resulting in the highest production of essential oil. For chamomile, the tested conditions do not favor the concentration of chamomile.

For the fertilizations with poultry manure, there was an increment in the content of essential oil as the irrigation depths increased. This result is different from that for aged bovine manure fertilization, since the content of essential oil decreased with the increase in irrigation depth. The results for fertilization are different from those of Mapeli et al. (2005), who observed that the fertilization did not influence the content of essential oil of chamomile and alpinia. Lopes et al. (2010) concluded that the organic management with the use of poultry litter resulted in the highest mean content of essential oil in chamomile plants. Costa et al. (2008) concluded that increasing doses of aged bovine manure and poultry manure resulted in the highest yield of essential oil of 'elixir paregórico' (Ocimum selloi).

The yield of essential oil (Figure 4B) was higher at the irrigation depth of $150 \%$ ETo, associated with the poultry manure fertilization at the dose of $5 \mathrm{~kg} \mathrm{~m}^{-2}$. Considering the fertilization with aged bovine manure, regardless of the irrigation depth, there was no significance in the results of yield of essential oil. Rosal et al. (2009) observed that the increase in

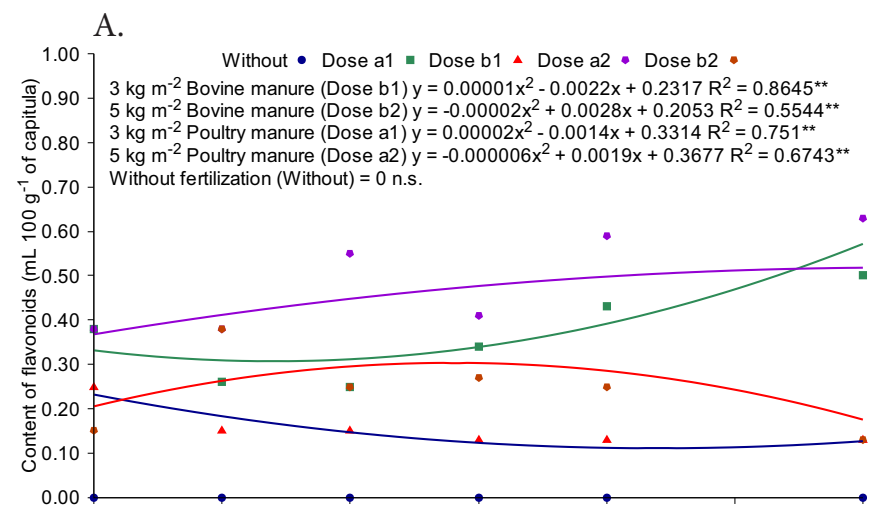

B.

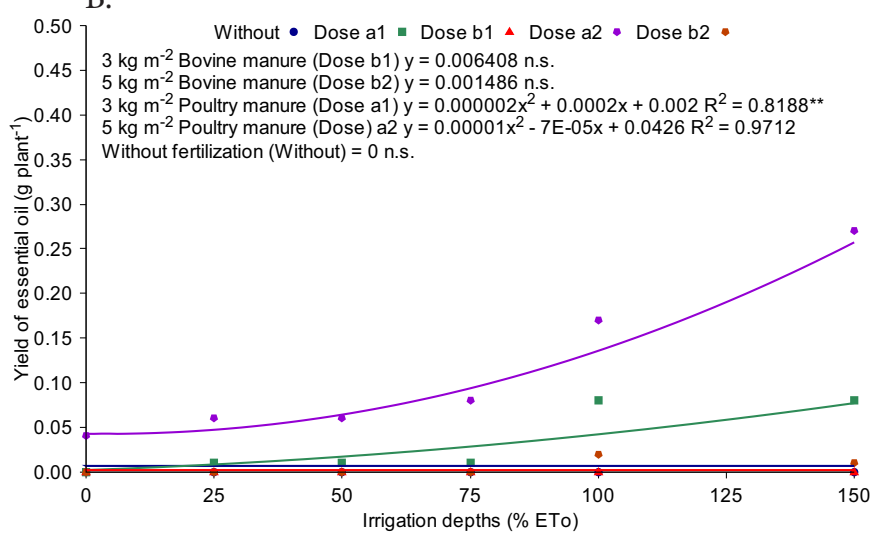

Figure 4. Content (A) and yield (B) of essential oil in the capitula of chamomile subjected to different irrigation depths (150, 100, 75, 50, 25 and 0\% ETo) and organic fertilization using bovine manure (b) and poultry manure (a), both at the doses of $3 \mathrm{~kg} \mathrm{~m}^{-2}$ (b1 and a1) and $5 \mathrm{~kg} \mathrm{~m}^{-2}$ (b2 and a2), respectively 
the dose of aged bovine manure resulted in the increment of the essential oil yield of 'boldo pequeno' (Plectranthus neochilus). Pinto (2010) concluded that the water stress or the decrease in irrigation depth resulted in the highest production of essential oil of lemon grass, for favoring the synthesis of this secondary metabolite as a response to the abiotic stress.

\section{Conclusion}

1. The irrigation depth of $150 \%$ ETo associated with the dose of $5 \mathrm{~kg} \mathrm{~m}^{-2}$ of aged poultry manure promotes higher production of flavonoids and essential oil in chamomile for the region of Presidente Prudente, SP.

\section{Literature Cited}

Afshar, A.; Afsharmanesh, G. R.; Adeli, M.; Malekian, A. Assessment of aquacrop model in the simulation of potato yield and water use efficiency under different water regimes. Journal of Biology Environment Science, v.8, p.79-86, 2014.

Allen, R. G.; Pereira, L. S.; Raes, D.; Smith, M. Crop evapotranspiration: guidelines for computing crop water requirements. Rome: FAO, 1998. 333p. Irrigation and drainage paper, 56

Alvarenga, I. C. A.; Queiroz, G. A.; Honório, I. C. G.; Valadares, R. V.; Martins, E. R. Prolina livre em alecrim-pimenta sob estresse hídrico antes da colheita. Revista Brasileira de Plantas Medicinais, v.13, p.539-541, 2011.

Amer, K. H.; Midan, A. S.; Hatfield, J. L. Effect of deficit irrigation and fertilization on cucumber. Agronomy Journal, v.101, p.1556-1564, 2009. http://dx.doi.org/10.2134/agronj2009.0112

ANVISA - Agência Nacional de Vigilância Sanitária. Farmacopéia brasileira. Brasília: ANVISA, 5.ed., 2010. 545p.

Bilibio, C.; Carvalho, J. A.; Martins, M.; Rezende, F. C.; Freitas, E. A.; Gomes, L. A. A. Desenvolvimento vegetativo e produtivo da berinjela submetida a diferentes tensões de água no solo. Revista Brasileira de Engenharia Agrícola e Ambiental, v.14, p.730-735, 2010. http://dx.doi.org/10.1590/S1415-43662010000700007

Borella, J. C.; Ribeiro, N. S.; Freato, A. M. R.; Mazzo, K. F.; Barbosa, D. M. Influência da adubação e da cobertura morta na produtividade e no teor de flavonoides de Calendula officinalis L. (Asteraceae). Revista Brasileira de Plantas Medicinais, v.13, p.235-239, 2011.

Bortolo, D. P. G.; Marques, P. A. A.; Pacheco, A. C. Teor e rendimento de flavonóides em calêndula (Calendula officinalis L.) cultivada com diferentes lâminas de irrigação. Revista Brasileira de Plantas Medicinais, v.11, p.435-441, 2009. http://dx.doi.org/10.1590/ S1516-05722009000400012

Côrrea, R. M.; Pinto, J. E. B. P.; Reis, E. S.; Costa, L. C. B.; Alves, P. B.; Nicuam, E. S.; Brant, R. S. Adubação orgânica na produção de biomassa de plantas, teor e qualidade de óleo essencial de orégano (Origanum vulgare L.) em cultivo protegido. Revista Brasileira de Plantas Medicinais, v.12, p.80-89, 2010.

Corrêa Júnior, C.; Scheffer, M. C. As plantas medicinais, aromáticas e condimentares e agricultura familiar. Horticultura Brasileira, v.32, p.376, 2014. http://dx.doi.org/10.1590/S0102-05362014000300023

Costa, L. C. B.; Pinto, J. E. B. P.; Castro, E. M.; Bertolucci, S. K. V.; Corrêa, R. M.; Reis, E. S.; Alves, P. B.; Niculau, E. S. Tipos e doses de adubação orgânica, no rendimento e na composição química do óleo essencial de elixir paregórico. Ciência Rural, v.38, p.21732180, 2008. http://dx.doi.org/10.1590/S0103-84782008000800013
EMBRAPA - Empresa Brasileira de Pesquisa Agropecuária. Centro Nacional de Pesquisa de Solos. Sistema brasileiro de classificação de solos. Brasília: Embrapa Produção da Informação, 2013. 412p.

Gobbo Neto, L.; Lopes, N. P. Plantas medicinais: Fatores de influência no conteúdo de metabólitos secundários. Química Nova, v.30, p.374-381, 2007. http://dx.doi.org/10.1590/S010040422007000200026

Kerbauy, G. B. Fisiologia vegetal. 2.ed. Rio de Janeiro: Guanabara Koogan, 2008. 431p.

Khan, M. M.; Hanif, M. A.; Abraham, A. S. Variations in basil antioxidant contents in relation to deficit irrigation. Journal of Medicinal Plants Research, v.6, p.2200-2223, 2012.

Lopes, A. P.; Santos, R. F.; Lucca, P. S. R.; Eckert, R. G. Manejos orgânico e convencional da camomila visando à produção de óleo essencial. Revista Varia Scientia Agrárias, v.1, p.45-54, 2010.

Mapeli, N. C.; Vieira, M. C.; Heredia, Z. N. A.; Siqueira, J. M. Produção de biomassa e de óleo essencial dos capítulos florais da camomila em função de nitrogênio e fósforo. Horticultura Brasileira, v.23, p.32-37, 2005. http://dx.doi.org/10.1590/S010205362005000100007

Meira, M. R.; Melo, M. T. P.; Martins, E. R.; Pinto, M. J. S.; Santana, C. S. Crescimento vegetativo, produção de fitomassa e de óleo essencial de Melissa officinalis L. sob diferentes lâminas de irrigação. Ciência Rural, v.43, p.779-785, 2013. http://dx.doi. org/10.1590/S0103-84782013005000040

Mitchell, A. E.; Hong, Y. J.; Koh, E.; Barret, D. M.; Bryant, D. E.; Denison, R. F.; Kaffka, S. Ten-year comparison of the influence of organic and conventional crop management practices on the content of flavonoids in tomatoes. Journal Agricultural Food Chemistry, v.55, p.6154-6159, 2007. http://dx.doi.org/10.1021/jf070344+

Pacheco, A. C.; Castro, P. R. C.; Sousa, G. M. Deficiência hídrica e aplicação de ABA nas trocas gasosas e no acúmulo de flavonoides em calêndula (Calendula officinalis L.). Acta Scientiarum Agronomy, v.33, p.275-281, 2011. http://dx.doi.org/10.4025/ actasciagron.v33i 2.6390

Pinto, D. A. Efeitos de lâminas de irrigação sobre as características de crescimento, produção e qualidade de óleo essencial de capimlimão. Viçosa: UFV, 2010. 71p. Dissertação Mestrado

Pinto, D. A.; Mantovani, E. C.; Melo, E. C.; Sediyama, G. C.; Vieira, G. H. S. Produtividade e qualidade do óleo essencial de capimlimão, Cymbopogon citratus, DC. submetido a diferentes lâminas de irrigação. Revista Brasileira de Plantas Medicinais, v.16, p.5461, 2014. http://dx.doi.org/10.1590/S1516-05722014000100008

Raij, B. van; Cantarella, H.; Quaggio, J. A.; Furlani, A. M. C. Recomendação de adubação e calagem para o Estado de São Paulo. Campinas: IAC, 2.ed., 1997. 285p.

Rosal, L. F.; Pinto, J. E. B. P.; Brant, R. S. Produção de biomassa e óleo essencial Plectranthus neochilus Schlechter cultivado no campo sob níveis crescentes de adubo orgânico. Pesquisa Aplicada \& Agrotecnologia, v.2, p.670-678, 2009.

Shock, C. C.; Wang, F. X. Soil water tension, a powerful measurement for productivity and stewardship. Hortscience, v.46, p.178-185, 2011.

Souza, A. V. V.; Souza, D. D.; Silva, F. P.; Santos, U. S.; Santos, M. S. F. J. V. Influência do estresse hídrico e adubação orgânica na produção e rendimento de óleo essencial de alecrim de tabuleiro. Horticultura Brasileira, v.30, p.6003-6009, 2012.

Taiz, L.; Zeiger, E. Fisiologia vegetal. 5.ed. Porto Alegre: Artmed, 2013. 918p. 
Tavano, E. C. R.; Tavares, A. R.; Takaki, M.; Lima, G. P. P. Conteúdos de compostos fenólicos e flavonoides em plantas de camomila (Matricardia recutita L. - Asteraceae) cultivadas in vivo e in vitro. Naturalia, v.32, p.67-77, 2009.
Verlag, D. A. Deustsches arzeibuch. Stuttgart: Gogi-Verlag GmBH, 1978. 680p.

Wagner, H.; Bladt, S. Plant drug analysis - A thin layer chromatography atlas. 2.ed. Berlin: Springer, 1995. 384p. 